\title{
MOLECULAR INDICATORS FOR TAXODIUM DUBIUM AS COAL PROGENITOR OF "CHUKUROVO" LIGNITE, BULGARIA
}

\author{
Stefanova M. \\ Institute of Organic Chemistry, Bulgarian Academy of Science, \\ Sofia 1113, BULGARIA maia@orgchm.bas.bg
}

\section{ABSTRACT}

The coal sediment under study was of Miocene/Pliocene geological age. The petrological data pointed to Tortonian/Sarmatian age, while the paleobotanical ones - to Middle Miocene. It was documented that "Chukurovo" basin was determined by coal facies indices as limnic ombrotrophic forester swamp. Fossilized trees predominated in "Chukurovo" lignites. Well preserved wood tissue of stems and twigs impregnated by clays and enriched in organic matter were macroscopically observed. Four types of phytocenosis - aquatic, swamp, flood plain, forests, i.e. mesophilous and mesohygrophilous were proposed. The composition of the last one confirmed the predominance of evergreen laurel and laurel-oaks communities during the Miocene.

In the present investigation tools of organic geochemistry were applied. Extractable matter from Taxodium dubium (Sternb.) Heer was studied by a sequence of extraction, separation and chromatographic identifications. The molecular data confirmed botanical assignment of the macrofossil to conifer family Taxodiaceae.

A lot of identified geolipids, i.e. alkanes, alcohols, fatty acids, and steranes/triterpanes were without chemosystematic value as ubiquitous in plant kingdom. Ferruginol, sugiol, totarol and products of their diagenetic transformations were identified as the dominant biomarkers. Ferruginol and its homologues were the most abundant phenols in Taxodium dubium (Sternb.) Heer. The biomarker composition of extractable matter strongly suggested that species of Cupressaceae ITaxodiaceae contributed in major amounts to "Chukurovo" paleoplant swamp.

\section{INTRODUCTION}

Terpenoids are highly abundant compounds in sediments, petroleum, coals, etc. They were used for correlation purposes (Philps 1985; Simoneit 1986; Waples \& Machihara 1991; Peters \& Moldowan 1993). Geolipids, or so-called "biomarkers", were studied with the aim to find biosynthetic pathway for transformation of potential progenitors. The possibility to find a relationship between distinct plant sources and macroscopically recognized species was attractive for geology, chemistry, botany, ecology, etc. Organic matter isolated from plant fossils was found to be suitable for chemosystematic purposes, inasmuch leaves, woods, twigs, cones, well characterized by paleobotany, might be assigned to certain precursors. According to Otto \& Wilde (2001) the terpenoids in conifers can provide valuable information about their phylogenetic relationships. The same authors have screened the available data for terpenoids and tried to relate them to certain extant conifers. The review covered all publications for the last half century.

The studies of terpenoids in the geosphere have dealt with saturated/aromatic fractions from bulk samples of coals, sədiments, etc. The present investigation was devoted to the biomarker assemblage of macroscopically identified Taxodium dubium (Sternb.)Heer. This macrofossil was botanically assigned by Palamarev (1989) as one of the most distributed progenitors of "Chukurovo" lignite, Bulgaria. Twigs and shoots of the fossil have been subjected to a geochemical study. The aim was to depict the main biomarkers for the macrofossil under study and to relate them to the conifer family Taxodiaceae. Respectively, the obtained information could be considered more precise comparing to the studies of bulk samples. There was already information with the same vision published for different classes of biomarkers, i.e. Knocke et al. (1967) for fossil Coniferales; Staccioli 
et al. $(1993,1996)$ for terpenes in fossil wood; Grantham \& Douglas (1980) for sesquiterpenoids in Tertiary resins; Otto et al. $(1997,1999)$; Otto \& Simoneit (2001) for sesqui- and diterpenoids in conifers, clays, sediments. Later on it was taken into consideration that after "in situ" preservation of the biomarker in the macrofossil it has sustained diagenetic transformation. Thus, the data gave unequivocal hints for coal burial, potential precursors and environmental alteration. Otto \& Simoneit (2001) have proposed diagenetic pathways for the degradation of abietic acid and phenolic abietanes. Such a sequence for transformtion could be proposed on the base of series of the altered abietane diterpenoids.

In this study the results for the lipids and terpenoids of Taxodium dubium (Sternb.)Heer, macrofossil preserved in the "Chukurovo" lignite, Bulgaria, paleobotanically distinguished as a potential coal precursor, will be described. The information will be interpreted in relation to different conifer families as well as the possibility for contamination by migration of organic matter from adjacent sediments. The study should be considered as a first attempt to correlate paleobotanical observations with chemical results and to be interpreted with a geological point of view for Bulgarian low rank coals.

\section{SAMPLE AND METHODS}

This study is focused on Sofia coal-bearing province. "Chukurovo" lignites are located in the vicinity of Sofia, $40 \mathrm{~km} \mathrm{SE}$, in a small valley of Lozen Mountain. Coals of this basin are of low rank and are exploited by o.jencast mining. Coal complex is represented by clays, sandy clays and sandstone with 12-18 coal seams (8-12 of industrial importance). At different positions the coal layers change their thickness, very often converting in coaly clays and sandy clays. These coal layers are covered with sandy clays and argillaceous sandstones (Kortenski 2002).

The coal-bearing sediments are of Miocene/Pliocene geological age, more precisely classified as Middle Miocene. The petrological studies pointed to Tortonian/Sarmatian age, while the paleobotanical ones (Palamarev 1989) - to Middle Miocene.

It was documented that "Chukurovo" basin was determined by coal facies indices as limnic ombrotrophic forester swamp. Fossilized trees predominated in "Chukurovo" lignites. Well preserved wood tissue of stems and twigs impregnated by clays and enriched in organic matter were macroscopically observed. Four types of phytocenosis - aquatic, swamp, flood plain, forests, i.e. mesophilous and mesohygrophilous, were proposed. The composition of the last one confirmed the predominance of evergreen laurel and laurel-oaks communities during the Miocene.

Bulk characteristics of "Chukurovo" lignites:

Coal-forming maximum - Neogene; $R_{0}, \%=0.20 \pm 0.02$;

Maceral composition, in vol.\%: Huminite, 75; Liptinite, 14; Inertinite, 1; Mineral matter, 10;

For mineral matter free (dmmf basis) - Huminite, 84; Liptinite, 15; Inertinite, 1;

Proximate analysis, \%: $W^{A}=8.8 ; A^{d}=20.5 ; V^{\text {daf }}=65.6$;

Ultimate analysis, wt \% daf: C - 67.9; H - 5.6; N -1.2; Sorg $-0.4 ; \mathrm{O}^{\text {diff }}-24.9$;

Macrofossil Taxodium dubium was paleobotanically classified by Palamarev (1989) and kindly provided for this study. The sample was crushed, sieved $(<0.2 \mathrm{~mm})$ and subjected to exhaustive Soxhlet extraction by benzene-ethanol (1:1). The solvent extract was filtered and concentrated at reduced pressure by rotary evaporator. The total sample was separated by open silica column $(10 \times 100 \mathrm{~mm})$ for isolation of saturated hydrocarbons as neutral fraction (hexane elution), aromatic hydrocarbons (toluene elution) and polar components (methanol elution).

Aliquots of aromatic and polar fractions were derivized by reaction with $\mathrm{N}, \mathrm{O}$-bis(trimethylsilyl)trifluoracetamide (BSTFA) according to Otto \& Simoneit (2001). GC-MS analyses of the fractions were performed on a Hewlett-Packard model 6890 GC coupled to a Hewlett-Packard model 5973 quadrupole MSD in conditions described in Stefanova et al. (2002).

\section{RESULTS AND DISCUSSION}

All mass spectrometrically identified compounds are given in Table 1. Structures of di- and triterpenoids as well as steranes and their derivatives are illustrated in appendix. 
The total extract amounted to $0.2 \mathrm{wt}$ \% of the sample subjected to Soxhlet extraction. It was shared as follows (in \% of sample under separation): neutral components, $7.4 \%$; aromatic components, $13.3 \%$ and polars, $59 \%$; The rest of the sample was irreversibly retained by the column.

\subsection{Aliphatic lipids}

The aliphatic lipids included the following homologous series:

$\mathrm{n}$ - Alkanes $-n-\mathrm{C}_{14}$ to $n-\mathrm{C}_{33}$, distributed in two series: - "mid"-chains members maximizing at $n-\mathrm{C}_{20}, n-\mathrm{C}_{21}, n-\mathrm{C}_{22}$ with a smooth distribution; - long chain serie with a strong dominance of "odd" members, $n-\mathrm{C}_{27}, n-\mathrm{C}_{29}, n-\mathrm{C}_{31}$.

Even carbon numbered n-alkanols from $n-C_{22}$ to $n-C_{26}$ were identified as well. Even-numbered $n$-alkanoic acids in the range $n-\mathrm{C}_{24}$ to $n-\mathrm{C}_{28}$ were presented. A broad serie of n-alkan-2-ones "odd" members, $n-C_{23}$ to $n-C_{33}\left(n-C_{29}\right.$ maximizing) has accompanied long chain alkanes distribution.

"Mid"-chain alcohol $n$-nonacosan-10-ol and its ketone 10-nonacosanone were highly abundant. They are common epicuticular wax components of higher plants.

Table 1. Compounds identified in Taxodium dubium (Sternb.) Heer

\begin{tabular}{|c|c|c|c|}
\hline \multirow[t]{3}{*}{ Compound name } & \multicolumn{3}{|c|}{ Fraction } \\
\hline & \multirow[t]{2}{*}{ Neutral } & \multicolumn{2}{|c|}{ Aromatic: } \\
\hline & & as eluted & as TMS \\
\hline \multicolumn{4}{|l|}{ Aliphatic lipids } \\
\hline$n$-Alkanes $n$ - $\mathrm{C}_{14}$ to $n-\mathrm{C}_{33}$ & + & & \\
\hline$n$-Alkan-2-ones (odd members) $n-C_{23}$ to $n-C_{33}$ ( $n$ - $C_{29} \max$ ) & + & & \\
\hline$n$-Alkanoic acids (even members) $n-C_{24}$ to $n-C_{28}$ & & & + \\
\hline n- Alkanols (even members) $n-C_{22}$ to $n-C_{26}$ & & & + \\
\hline 10-Nonacosanone, $\mathrm{C}_{29} \mathrm{H}_{58} \mathrm{O}$, MW 422 & + & & \\
\hline 10-Nonacosanol, $\mathrm{C}_{29} \mathrm{H}_{60} \mathrm{O}, \mathrm{MW} 424$ & & & + \\
\hline \multicolumn{4}{|l|}{ Diterpenoids } \\
\hline \multicolumn{4}{|l|}{ i.e. "Regular" diterpenoids } \\
\hline Fichtelite (I), $\mathrm{C}_{19} \mathrm{H}_{34}, \mathrm{MW} 262$ & + & & \\
\hline Dehydroabietane (II), $\mathrm{C}_{20} \mathrm{H}_{30}, \mathrm{MW} 270$ & + & & \\
\hline Simonellite (III), $\mathrm{C}_{19} \mathrm{H}_{24}, \mathrm{MW} 252$ & + & & \\
\hline $16 \alpha(\mathrm{H})$-Phyllocladane (IV) $\mathrm{C}_{20} \mathrm{H}_{34}, \mathrm{MW} 274$ & + & & \\
\hline \multicolumn{4}{|l|}{ i.e. Phenolic diterpenoids } \\
\hline Ferruginol $(\mathrm{V}) \mathrm{C}_{20} \mathrm{H}_{30} \mathrm{O}$, MW 286 & + & + & + \\
\hline Totarol (VI) $\mathrm{C}_{20} \mathrm{H}_{30} \mathrm{O}, \mathrm{MW} 286$ & & + & + \\
\hline Sugiol (VII) $\mathrm{C}_{20} \mathrm{H}_{28} \mathrm{O}_{2}, \mathrm{MW} 300$ & & & + \\
\hline \multicolumn{4}{|l|}{ Steranes } \\
\hline 5a-Stigmastan-3-one (VIII) $\mathrm{C}_{29} \mathrm{H}_{50} \mathrm{O}$ MW 414 & & + & + \\
\hline $5 \beta$-Stigmastanol (IX) $\mathrm{C}_{29} \mathrm{H}_{52} \mathrm{O}$ MW 416 & & & + \\
\hline \multicolumn{4}{|l|}{ Triterpenoids } \\
\hline \multicolumn{4}{|l|}{ i.e. Hopanes, Hopene } \\
\hline $\mathrm{H}_{17 \beta} ; \mathrm{H}_{30 \alpha \beta} \mathrm{H}_{31 \beta \beta ;} ; \mathrm{H}_{31 \alpha \beta \beta} ; \mathrm{H}_{27 \beta ; 1} \quad(X)$ & + & & \\
\hline \multicolumn{4}{|l|}{ I.e. Non-hopanoids } \\
\hline Fernene $(\mathrm{XI}) \mathrm{C}_{30} \mathrm{H}_{50} \mathrm{MW} 410$ & + & & \\
\hline Friedelin (XII) $\mathrm{C}_{30} \mathrm{H}_{50} \mathrm{O} \mathrm{MW} 426$ & & + & + \\
\hline$\alpha$-Amirin (XIII) $\mathrm{C}_{30} \mathrm{H}_{50} \mathrm{O}$ MW 426 & & + & + \\
\hline$\beta$-Amirin (X_V) $\mathrm{C}_{30} \mathrm{H}_{50} \mathrm{O} \mathrm{MW} 426$ & & + & + \\
\hline$\beta$-Amiron $(X \bar{V}) \mathrm{C}_{30} \mathrm{H}_{48} \mathrm{O}$ MW 424 & & + & + \\
\hline Allobetulone $(X V I) \mathrm{C}_{30} \mathrm{H}_{48} \mathrm{O}_{2} \mathrm{MW} 440$ & & + & + \\
\hline
\end{tabular}




\subsection{Diterpenoids}

The diterpenoids in Table 1 can be assigned to abietane, phyllocladane and totarane structural groups. $16 \alpha(\mathrm{H})$-Phyllocladane (IV) strongly dominated in neutral fraction while abietanes were represented as hydrocarbons (fichtelite, Str.I), aromatic (dehydroabietane, Str.II; simonellite, Str. III) and phenolic derivatives (ferruginol, Str. V, traces of ketophenol sugiol, Str. VII). Totarol (Str. VI) was enriched in the aromatic fraction.

According to Otto \& Wilde (2001) the reports of abietane derivatives reveal two groups with different distribution, the "regular" abietanes and the "phenolic" abietanes. The latter, i.e. ferruginol, sugiol and their derivatives, are widely distributed in the conifer families, especially Cupressaceae s.str., Taxodiaceae, and Podocarpaceae, but seem to be largely absent in Pinaceae. The other phenol derivative with tricyclic structure, totarol, in spite of its low quantity, was a chemosystematic marker for Cupressaceae s. str., Podocarpaceae and confirmed above mentioned families.

The tetracyclic diterpenoids occur in conifers mostly as hydrocarbons, i.e. kaurane, hibaene and phyllocladane. The last one was the hydrocarbon in high preponderance in neutral fraction of the total extract. Phyllocladane-type diterpenoids have not been found in Pinaceae but have been observed in genera of all other conifer families, i.e. Cupressaceae s.str., Podocarpaceae, Araucariaceae, Taxodiaceae, etc.

\subsection{Steroids}

Polar steroids stign.astanol (IX) and its ketone counterpart (VIII) were present in the fossil extract. These compounds were described in fossil conifer extracts by Otto et al. (2001). Steroids $C_{28}$ and $\mathrm{C}_{29}$ are highly abundant in plant kingdom and reflect the input of detritus from higher plants (Oros \& Simoneit 1999). These compounds are nonspecific markers, because the biological precursor $\beta$-sitosterol is ubiquitous.

\subsection{Triterpenoids}

Triterpenoids were divided in hopanoids $(X)$ and non-hopanoids (XI to XVI)(Table 1). Hopanoids contained the serie $\mathrm{C}_{27}$ to $\mathrm{C}_{31}\left(\mathrm{C}_{28}\right.$ absent). There was one unsaturated hopane $\mathrm{C}_{27: 1}$ as well. Hopanoids indicate a microbial activity. However some hopanoids also occur in peat and might be derived in part from lower plants like mosses and ferns.

Aromatic and polar pentacyclic triterpenoids were registered in all fractions: fernene $(X I)$ and $\alpha / \beta$ amyrins/amyrons (XIII to XV) as well as trace of allobetulone (XVI) in neutral and a lot a phenols in aromatic one. Dominant triterpenoid in aromatic fraction was friedelin (XII). Rather similar assemblage of triterpenoids was described by Otto et al. (2001) for Taxodium dubium preserved in Lipnika Wielka, Poland. Namely, few terpenoids (friedeline, $\alpha / \beta$ amyrin), steroids ( $\beta$-sitosterol and stigmastanol) and high aliphatic wax constituent n-nonacosan-10-ol were determined. The authors concluded that diterpenoids represented probably the original terpenoids of the macrofossil while triterpenoids were prevailing in surface waxes or the easily degraded leaves of angiosperms. Respectively, triterpenoids were considered as contamination of the samples with organic sedimentary particles originated from detritus and waxes of angiosperm origin. A similar result were described by Otto \& Simoneit (2001) for terpenoids in Eocene conifer shoots from Zeitz, Germany.

\section{CONCLUSIONS}

The molecular data confirmed botanical assignment of the macrofossil to conifer family Taxodiaceae. There was not a great chemical heterogeneity in Taxodiaceae genera, especially there were not sesquiterpenoids. On the base of literature data the main species could be attributed to certain families:

1. $16 \alpha(\mathrm{H})$-Phyllocladane to all conifer families except Taxaceae and rare in Pinaceae;

2. Phenolic abietanes i.e. ferruginol, sugiol and totarol, to Cupressaceae s. str., Taxodiaceae, Po docarpaceae, Araucariaceae; 
The obtained results indicated that only phenolic diterpenoids were preserved in macrofossil and could be used as chemosystematic markers for the phylogenetic and systematic comparison of the fossil taxa.

\section{AGKNOWLEDGEMENTS}

The study was performed with the financial support of National Science Fund of Ministry of Education and Science (Grant No1312). The author would like to express her gratitude to Prof. E. Palamarev from Botanical Institute, Bulgarian Academy of Science for providing the macrofossil sample. Prof. B.R.T.Simoneit and Dr. A.Otto from Oregon State University, USA are greatly acknowledged for GC-MS separations, derivatizations, useful discussions and help to improve the manuscript.

\section{REFERENCES}

Grantham P., \& Douglas A. 1980. The nature and origin of sesquiterpenoids in some Tertiary fossil resins. Geochimica et Cosmochimica Acta, 44, 1801-1810.

Knoche H., Albrecht P. \& Ourisson G. 1967. Organic compounds in fossil plants (Voltzia brongniarti, Coniferales). Angew. Chemie, Inter. Edition, 7,631.

Kortenski J. 2002. Coal geology and organic petrology. MGU Publ. House, Sofia, 219 pp (in Bulgarian).

Oros D. \& Simoneit B. 1999. Identification of molecular traces in organic aerosols from temperature climate vegetation subjected to biomass burning. Aerosol Sci. and Tech., 31, 433-445.

Otto A., Walther H. \& Puttmann W. 1997. Sesqui- and diterpenoid biomarkers preserved in Taxodium-rich Oligocene oxbow lake clays, Weisselster basin, Germany. Organic Geochemistry, 26, 105-115.

Otto A. \& Wilde, V 2001. Sesqui-, di- and triterpenoids as chemosystematic markers in Extant conifers-a review. Botanical Review, 67, 141-238.

Otto A. \& Simoneit B. 2001. Chemosystematics and diagenesis of terpenoids in fossil conifer species and sediment from the Eocene Zeitz formation, Saxony, Germany. Geochimica et Cosmochimica Acta, 65, 3505-3527.

Otto A., Simoneit B., Lesiak M., Wilde V. \& Worobiec G. 2001. Resin and wax biomarkers preserved in Miocene Cupressaceae s. 1 from Belchatow and Lipnica Wielka, Poland. Acta Paleobot. 41, 195-206.

Palamarev E. 1989. New paleofloristic data of the Miocene in the Chukurovo coal basin and its paleoecologic and biostratigraphic significance. Paleont. Stratigr. and Lithol., 27, 44-64 (in Bulgarian).

Philp R.P. 1985 Fossil Fuel Biomarkers. Applications and Spectra. Elsevier, Amsterdam, 292 pp.

Peters K. \& Moldowan J. 1993. Terpanes. In: The Biomarker Guide Interpreting Molecular Fossils in Petroleum and Ancient Sediments, Prentice Hall, Englewood Cliffs, NJ 07632, pp.171-174.

Simoneit B. 1986. Cyclic terpenoids of the geosphere. In: Biological markers in the sedimentary record. John R.B. (Ed.) Elsevier, Amsterdam, Oxford, NY, Tolyo, pp. 43-101.

Staccioli G., Mellerio G. \& Alberti M. 1993. Investigation of terpene-related hydrocarbons from Pliocenic fossil wood, Holzforschung, 47, 339-342.

Staccioli G., Menchi G. \& Matteoli U. 1996. Taxodioxylon gypsaceum as parent botanical species of two lignites of Central Italy, Holz als Roh-und Werkstoff, 54, 259-261.

Stefanova M., Oros D., Otto A. \& Simoneit B. 2002. Polar aromatic biomarkers in the Miocene Maritza-East lignite, Bulgaria, Org. Geochemistry, 33, 1079-1091.

Waples D.W. \& Machihara T. 1991 In: Biomarkers for geologists, Am. Assoc. Petr. Geologists, Tulsa, Oklahoma, pp. 1-91. 


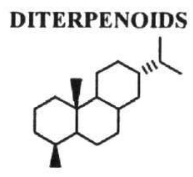

I. Fichtelite

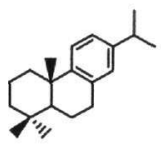

II. Dehydroabietane

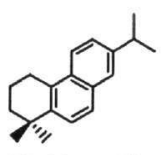

III. Simonellite

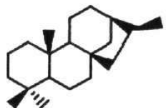

IV.16a(H)-Phyllocladane<smiles>CC(C)c1cc2c(cc1O)[C@]1(C)CCCC(C)(C)[C@H]1CC2</smiles>

V. Ferruginol

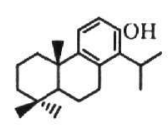

VI. Totarol

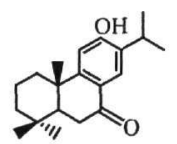

VII. Sugiol

STERANES

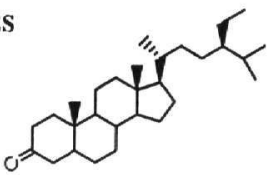

VIII. 5 $\alpha$-Stigmastan-3-one

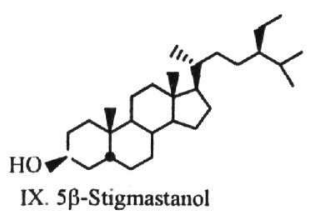

IX. $5 \beta$-Stigmastanol

TRITERPENOIDS

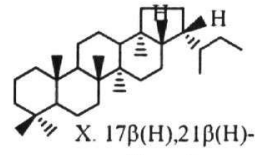

Homohopane

$\left(\mathrm{H}_{31 \beta \beta}\right)$

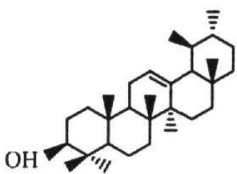

XIII. $\alpha$-Amyrin

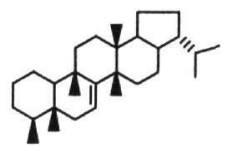

XI Fernene

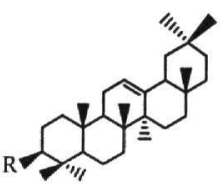

XIV. $\beta$-Amyrin $(\mathrm{R}=\mathrm{OH})$ $X V$. $\beta$-Amyron $(\mathrm{R}=\mathrm{O})$

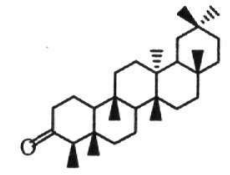

XII Friedelin

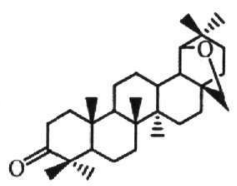

XVI. Allobetulone 